\title{
Charismatic and Transformational Leadership Styles: A Cross-Cultural Perspective
}

\author{
Rakesh Mittal ${ }^{1}$ \\ ${ }^{1}$ School of Management, New York Institute of Technology, Old Westbury, New York, U.S.A \\ Correspondence: Rakesh Mittal, School of Management, New York Institute of Technology, Old Westbury, New \\ York, U.S.A. E-mail: rmittal@nyit.edu
}

Received: August 18, 2014

Accepted: December 24, 2014

Online Published: February 27, 2015

doi:10.5539/ijbm.v10n3p26

URL: http://dx.doi.org/10.5539/ijbm.v10n3p26

\begin{abstract}
Culture's influence on leadership processes is generally accepted. However, differing leadership styles will be differentially impacted by the cultural context in which they seek to operate. The current paper examines two seemingly similar but distinct leadership styles, charismatic leadership and transformational leadership in the context of cultural dimensions of individualism-collectivism and tightness-looseness. A conceptual framework is presented to describe the interaction of these leadership styles and cultural dimensions. It is argued that charismatic leadership would be the preferred leadership style in individualistic and loose societies, whereas transformational leadership style would be more acceptable in collectivistic and tight societies. These insights have practical implications for design of leadership intervention programs for businesses spanning more than one culture.
\end{abstract}

Keywords: charismatic, transformational, cross-cultural, leadership, tightness-looseness, individualism-collectivism

\section{Introduction}

Although numerous definitions of leadership exist, several scholars view leadership as an individual's ability to influence and motivate others towards the success of the organization of which they are members (Dorfman, 2004; House et al., 1999; Javidan \& Carl, 2005). The modern theories of leadership recognize that the leadership process is not merely "give and take" towards achievement of a logical goal, but can frequently result in performance beyond expectations and logic (Bass, 1985; Yukl, 2002). Charismatic and transformational theories of leadership are two theories which explain how leaders influence followers to make self-sacrifices and put the needs of the mission or organization above their materialistic self-interests. Seemingly similar, there are important differences between these theories, particularly in the underlying influence processes (Yukl, 1999).

Since the conceptualization of leadership revolves around influence and influencing, it is inherently culture-sensitive. Culture signifies the basic values and belief systems of individual that are expected to impact managerial processes and leadership mechanisms. Numerous studies on cross-cultural leadership (e.g., Ayman, 2004; Bass, 1997; Dorfman, 2004; Gelfand, Erez, \& Aycan, 2007; House, Wright, \& Aditya, 1997) have demonstrated that leadership is conceptualized differently in different cultures. Simply put, an understanding of cultural forces is important to fully comprehend the leadership processes. However, it is not yet clear exactly how culture shapes leadership. The current paper examines two leadership styles; charismatic leadership and transformational leadership for their cultural acceptability, focusing on the cultural constructs of individualism-collectivism and tightness-looseness.

The conceptual exploration in the current paper encompasses two important cultural constructs. It is acknowledged that some other cultural values such as power distance or uncertainty avoidance also have a bearing on the leadership styles existing in a given cultural context. But it is felt that examining individualism-collectivism and tightness-looseness within a single framework is nevertheless useful because it enables a more fine grained analysis of these similar yet distinct cultural constructs vis-à-vis leadership, without the confounding effect of other cultural values. The literature on cross-cultural leadership has generally taken a dimension-based approach to study the impact of cultural on leadership. By integrating the construct of cultural tightness-looseness in the framework, the current paper provides a new perspective to explore the cultural sensitivity of such leadership styles that seem similar to the naked eye. 


\section{Theoretical Background}

\subsection{Charismatic and Transformational Leadership}

Charisma is a Greek word that means "divine gift", such as the ability to perform miracles. This word was applied by Weber (1947) to describe leader influence, emanating not from formal authority but from follower perceptions of the leader being endowed with exceptional qualities. Charismatic leaders arouse enthusiasm and commitment in followers by articulating a compelling vision and increasing follower confidence about achieving it. By acting confidently in innovative and effective ways, the charismatic leader achieves radical change in the organization and is judged by its members to have achieved unusual success (Conger \& Kanungo, 1987, 1998). Thus, an attribution of charisma is the result of followers' perception of the leader-Charisma is in the eye of the beholder.

Charismatic leaders have been known to have had a tremendous influence on an organization and its performance, though not always beneficial (Yukl, 2002). Scholars have pointed out that there can also be a "dark side" to charismatic leadership (Conger, 1990; House \& Howell, 1992) which can eclipse the bright side to the detriment of both the leader and the organization, by introducing instability and uncertainty into management and decision-making processes.

Transformational leadership is another theory that describes how effective leaders inspire and transform followers by appealing to their ideals and emotions. Though the term "transformational leadership" was first used by Burns (1978), a formal presentation of transformational leadership was made by Bass (1985) by including a model and factors of behavior. Transformational leaders make followers more aware of the importance and value of their work, thereby inducing them to transcend self-interest for the sake of the organization. The leaders develop follower skills and confidence to prepare them to assume more responsibilities. As a result, followers trust the leader and are motivated to do more than originally expected to do (Yukl, 2002). Several empirical studies have demonstrated the positive impact of transformational leadership on follower motivation, commitment and empowerment (Bass \& Avolio, 1990; Berson, Shamir, Avolio, \& Popper, 2001; Masi \& Cooke, 2000).

Some scholars (Bass, 1985; Shamir, 1991) use the terms charismatic leadership and transformational leadership interchangeably, perhaps because both leadership styles are similar in terms of outcomes, that of performance beyond expectations. But there are important distinctions between these styles (Barbuto, 1997). For example, the essence of leader charisma is being perceived by followers as extraordinary. In such a situation of attributed charisma, followers are dependent on the leader for guidance and inspiration (Antonakis, 2001; Graham, 1987). On the other hand, the essence of transformational leadership is inspiring and stimulating followers to develop themselves. Thus a successful transformational process could act to reduce attribution of charisma towards the leader (Yukl, 1999).

Other important differences exist in some leadership behaviors in these styles. Transformational leaders do more things that will empower their followers and make them less dependent on the leader (Gardner, 1989). Charismatic leaders, on the other hand, usually engage in behaviors that foster an image of extraordinary competence and thus increase follower dependence (Downtown, 1973; Yukl, 1999).

Lastly, and perhaps most importantly, charismatic and transformational leadership styles differ in terms of the mechanisms of the underlying influence processes. It should be noted that leadership scholars have adopted two broad approaches to defining leadership; one views it as an individual's ability to influence and motivate others towards the success of the organization of which they are members (House et al., 1999), while the other approach treats leadership as a process of social influence in which one person is able to enlist the aid and support of others in the accomplishment of a common task (Chemers, 1997). Charismatic influence processes are primarily intended to align followers' vision with that of the leader. Thus, the influence process is one-way. In transformational leadership on the other hand, there is mutuality in the leader-follower relationship that has implications of both leader and follower being simultaneously "transformed". Thus the influence process is reciprocal (Bailey, 2001; Miller, 2007).

\subsection{Culture and Leadership}

Since the 1980s there has been a growing realization that cross-cultural differences in leadership practices need to be studied in greater detail and understood better for successful conduct of cross-border businesses. The impact of cultural factors on leadership phenomenon is important; both from a practical point of view-need of firms to be competitive in an increasingly global environment, and from a scientific viewpoint-need to develop theories of cross-cultural leadership (Dorfman, 2004). In a multi-cultural environment, leaders need to 
effectively deal with situations that are complex, constantly evolving and difficult to interpret (Yukl, 2002). The empirical literature on cross-cultural leadership has been developing to describe how the role of culture influences perception and enactment of leadership (see Ayman, 2004; Bass, 1997; Dorfman, 2004; Gelfand et al., 2007; House et al., 1997). However, culture being a multi-faceted and multi-layered construct, the exact mechanism of interaction of culture and leadership is not yet fully clear.

Efforts to fully comprehend the culture-leadership relationship are further complicated by the conceptualization of culture. Although a dimension-based interpretation of culture has predominantly been used in studies relating culture to management processes (see Taras, Kirkman \& Steel, 2010 for a meta-analytic review), scholars are divided over how many dimensions culture can be composed into. In a seminal research on culture, Hofstede (1980) empirically derived four dimensions of culture but added a fifth dimension later (Hofstede \& Bond, 1988). Later, an empirical study by Schwartz (1992) described seven dimensions of culture. The most recent effort in this direction was that of the Global Leadership and Organizational Behavior Effectiveness (GLOBE) research project that empirically derived nine cultural dimensions (Javidan, House, \& Dorfman, 2004).

However, despite a variation in the exact number of cultural dimensions, several scholars (Hofstede, 1980, 1988; Javidan et al., 2004; Triandis, 1995) are in agreement that individualism-collectivism is one of the most influential dimensions of culture that describes the individual-society interface. According to Vandello \& Cohen (1999), "one of the most useful and actively researched construct to emerge from cultural social psychology has been the dimension of individualism-collectivism" (p. 279). The individualism-collectivism dimension of culture describes the relationship between the individual and the collectivity that prevails in a given society (Hofstede 1980, 1991). It is reflected in the way people live together - for example in nuclear families, extended families or tribes - and has implications for value and behavior. Individualism emphasizes personal freedom and achievement (Schwartz, 1992). Individualist culture therefore awards social status to personal accomplishments such as important discoveries, innovations, great artistic or humanitarian achievements and all actions that make an individual stand out (Markus \& Kitayama, 1991). Collectivism, in contrast emphasizes embeddedness of individuals in a larger group. It encourages conformity and discourages individuals from dissenting and standing out (Miller, 1994). In such societies, individuals can expect their relatives, clan, or other in-group to look after them in exchange for unquestioning loyalty. The key issue is the degree of interdependence a society maintains among individuals. In some cultures, such as Anglo-Saxon, individualism is seen as a blessing and a source of well-being; in others, such as the East Asian, it is seen as a sign of alienation and is therefore discouraged (Dorfman \& House, 2004).

Another similar, yet distinct concept is that of tightness-looseness of culture (Gelfand, Nishii \& Raver, 2006; Triandis, 1994). Although cross-cultural management research has primarily relied on cultural value dimensions such as those described by Hofstede (1980), Trompenaars (1993), and others, to understand cultural differences in behavior, researchers have noted (Bond, Leung, Tong \& Chemonges-Nielson, 2004; Earley \& Mosakowaski, 2002) that cultural values may not be treated as the sole predictor of individual responses, and that external norms and constraints need to be considered for a fuller understanding (Gelfand et al., 2006). The concept of tight and loose cultures focuses on the strength of social norms and the degree of sanctioning within societies, in a bid to understand behavior. Tight cultures (Pelto, 1968) have clear norms that are reliably imposed: deviation from normative behavior invites severe sanctions from society. Loose cultures, on the other hand, frequently have unclear norms about most social situations or tolerate deviance from the norms. Generally, homogenous societies, such as Japan, exhibit more tightness than heterogeneous societies such as the USA (Triandis, 1989). Historically, agrarian societies are more likely to develop into tighter collectives than hunting and gathering societies (Boldt, 1978), since the former require clear norms to enforce the coordination necessary to produce crops for survival.

Although, prima facie, the concept of tightness-looseness appears parallel to the cultural dimension of individualism-collectivism, the two are distinct (Carpenter, 2000; Triandis, 1989). Individualism-collectivism is concerned with the emphasis placed by societies on strong in-group ties versus being independently oriented - it does not refer to how much tolerance there is for deviance from norms. There are societies or groups that are generally collectivistic and loose (e.g., Brazil), collectivistic and tight (e.g., Japan, Singapore), individualistic and loose (e.g., the United States, New Zealand), and individualistic and tight (e.g., Germany; cf. Gelfand et al., 2006).

Since both individualism-collectivism and tightness-looseness deal with individual behavior in societal context, the objective of the current paper is to conceptually examine whether these constructs can be differentiated in their impact on charismatic and transformational leadership. Such a conceptual exploration would foster an understanding of which leadership style might be more suitable in a particular cultural context. 


\subsection{Individualism-Collectivism and Leadership}

The ability to influence or the process of influencing is the direct consequence of the way in which social power is used in leader-follower interaction (French \& Raven, 1959). Charismatic leaders' influence stems from the power bases of expert and referent power (French \& Raven, 1959; Lunenburg, 2012). In an individualistic society, individuals are encouraged to acquire knowledge, expertise and skills to develop themselves. Individual achievements are expected and appreciated (Markus et al., 1991). These values resonate with charismatic leadership in which the leader is attributed as larger than life, and hence worthy to be emulated and followed. In collectivist cultures, on the other hand, there is more emphasis on group goals than personal goals; more recognition of group efforts which can only be achieved by developing the members of the collective (Triandis, 1989). Such values would resonate more with the transformational style of leadership because of its focus on followers' empowerment and development. The following propositions are offered:

P1: Individualistic societies are likely to encourage, develop and witness more charismatic leadership than transformational leadership

P2: Collectivistic societies would be more favorable and amenable to transformational leadership than charismatic leadership

\subsection{Tightness-Looseness and Leadership}

In a tight culture, social norms are strong and strictly enforced (Gelfand et al., 2006). Charismatic leaders are frequently characterized by behavior that is risk-taking and challenging the status quo (Yukl, 2002). Indeed, their charisma is boosted by their being different from others and possessing extraordinary abilities (Conger et al., 1987). These values are not in congruence with a tight culture. On the other hand, transformational leaders, by drawing on the position and legitimate bases of power, would find more acceptance in tight cultures. Conversely, in a loose culture, people's idiosyncratic behavior is accepted and deviance is not severely punished. These conditions are conducive to emergence and acceptance of charismatic leadership in such societies. It was pointed out earlier that charismatic leadership can sometimes be harmful to the organization (Yukl, 1999). This dark side of charismatic leadership can be linked to increased levels of tolerance in a loose society. The following propositions are offered:

\section{P3: Societies with tight culture would favor transformational leadership more than charismatic leadership}

\section{P4: Societies with loose culture would be conducive to emergence and acceptance of charismatic leadership}

It should be noted that the purpose of this paper is not to portray charismatic and transformational leadership as two opposite ends of a spectrum. Rather, there are many instances where leaders can both be transformational as well as charismatic (Bass \& Avolio, 1993; House \& Shamir, 1993). The intention of juxtaposing these leadership styles with the cultural dimensions in this paper is to highlight the importance of cultural context in indicating which leadership style might be more acceptable and effective in a society.

By combining the above theoretical propositions, it is possible to argue that societies which are individualistic and loose are more apt to witness the emergence and operation of charismatic leadership. On the other hand, societies which are collectivistic as well as tight would facilitate the emergence and practice of transformational leadership styles. Furthermore, societies which are individualistic and tight or collectivistic and loose would have a mix of both charismatic and transformational styles. This can be visually depicted in the form of a matrix as shown in figure 1.

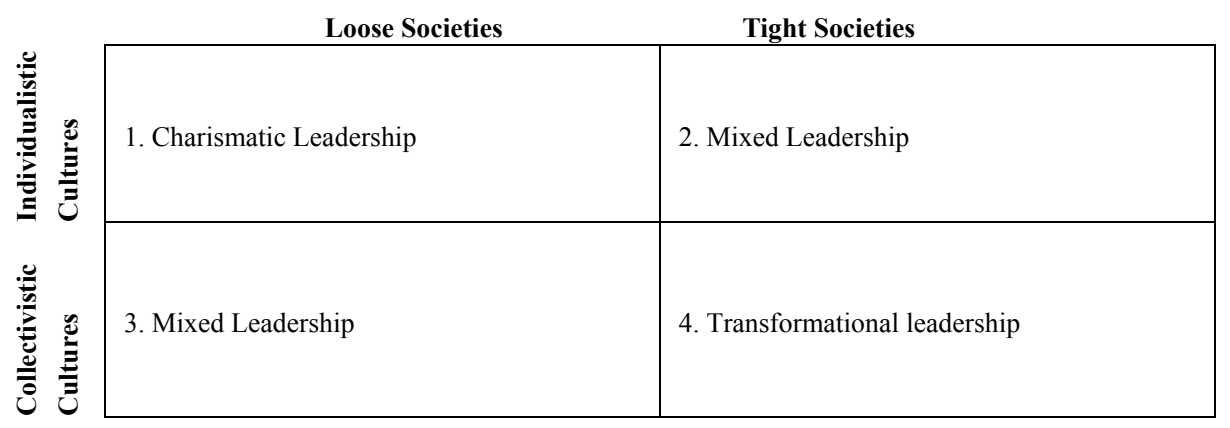

Figure 1. Preferred leadership styles in different cultural quadrants 


\section{Discussion and Directions for Future Research}

The framework proposed in this paper should help us to understand why certain leadership styles find more fertile ground to develop in some societies but not in others. There is prima facie support available for the propositions outlined in this paper when countries are categorized on the basis of the cultural dimensions examined in this paper. A number of empirical studies have measured the various dimensions of culture in different countries/societies. For example, a meta-analysis by Taras, Kirkman and Steel (2010) reported country scores for the cultural dimension of individualism-collectivism. A 33-nation study by Gelfand et al. (2011) reported on tightness and looseness scores of 33 nations. A study of these findings indicates that countries such as USA and New Zealand can be classified as individualistic and loose societies. Thus these countries would fall in the first quadrant of the matrix, where charismatic leadership might thrive according to the framework presented in this paper. It is notable that in the GLOBE study of 62 societies (Javidan et al., 2004) it was found that charismatic/value-based leadership was endorsed very highly as an outstanding leadership style in USA and New Zealand, with country scores above 6.0 on a 1 to 7 Likert scale. The history of USA is replete with the instances of emergence and success of a number of charismatic leaders, some notable names being Martin Luther King Jr., Franklin D. Roosevelt, and John F. Kennedy. In more recent context, names of charismatic leaders such as Bill Clinton or Steve Jobs can be mentioned. In New Zealand too, a historical view lends credence to emergence of successful charismatic leaders such as Kate Sheppard, Roger Douglas, and David Lange.

The fourth quadrant of the matrix shown in figure 1 is signified by societies that are high in collectivism and tightness. Based on the predominant cultural values reported in studies referred to above, countries that can be said to represent this quadrant are Japan and China. Here too, a historical perspective lends support to the proposition that such societies would be more conducive to emergence and operation of transformational leadership. Both of these countries are known for acceptance and operation of transformational leaders. Chen and Farh (1999) found that transformational leadership was the most applicable to Chinese leadership situations. To many, Deng Xiaoping was a perfect example of a transformational leader (Peter \& James, 2013). In Japan too, Yokochi (1989) found the transformational leadership to be the most prevalent.

The dynamics in the second and third quadrant of our matrix is a bit more complex since the relevant cultural dimensions seem to favor different leadership styles. It is expected that countries falling in collectivistic and loose quadrant, such as Brazil and Greece, while those in the individualistic and tight category, such as are Germany and Norway would witness a mix of both charismatic and transformational leadership styles. An empirical examination of this framework should be possible by collecting data about popular and prevalent leadership styles in different countries and relating it to the cultural dimensions of individualism-collectivism and tightness-looseness.

It is hoped that the conceptual framework described in this paper would augment an understanding of cross-cultural leadership. Furthermore, a knowledge of which leadership styles are more acceptable in a given society also has practical implications for design of leadership intervention programs and for selecting and preparing senior executives to take on leadership roles in cross-border business activities.

Two important cultural constructs were the focus of this paper. While acknowledging that some other cultural dimensions could also have a bearing on the leadership styles in a given cultural context, it is nevertheless felt that examining individualism-collectivism and tightness-looseness within a single framework enables a more fine grained analysis of these similar yet distinct cultural constructs vis-à-vis leadership, thus enhancing the understanding of this complex phenomenon. In any empirical examination of the framework presented here, it is recommended to control for other cultural dimensions to fully comprehend the nuances of differential acceptance of charismatic and transformational leadership in tight or loose cultures.

\section{References}

Antonakis, J. (2001). The validity of the transformational, transactional and laissez-faire leadership model as measured by the Multifactor Leadership Questionnaire (MLQ5X). Dissertation Abstracts International, 62(1), 233.

Ayman, R. (2004). Situational and contingency approaches to leadership. In J. Antonakis, A. T. Cianciolo, \& R. J. Sternberg (Eds.), The nature of leadership (pp. 148-170). Thousand Oaks, CA: Sage.

Bailey, J. (2001). Leadership lessons from Mount Rushmore: An interview with James MacGregor Burns. Leadership Quarterly, 12(1), 113-128. http://dx.doi.org/10.1016/S1048-9843(01)00066-2

Barbuto, J. E. (1997). Taking the charisma out of transformational leadership. Journal of Social Behavior and Personality, 12, 689-697. 
Bass, B. M. (1985). Leadership and performance beyond expectations. New York: Free Press.

Bass, B. M. (1997). Does the transactional-transformational leadership paradigm transcend organizational and national boundaries? American Psychologist, 52(2), 130-139. http://dx.doi.org/10.1037/0003-066X.52.2.130

Bass, B. M., \& Avolio, B. J. (1993). Transformational leadership: A response to critiques. In M. M. Chemers \& R. Ayman (Eds.), Leadership theory and research: Perspectives and directions (pp. 49-80). San Diego: Academic Press.

Bass, B. M., \& Avolio, B. J. (1990). Transformational leadership development: Manual for the Multifactor Leadership Questionnaire. Palo Alto, CA: Consulting Psychological Press.

Berson, Y., Shamir, B., Avolio, B. J., \& Popper, M. (2001). The relationship between vision strength, leadership style, and context. The Leadership Quarterly, 12, 53-73. http://dx.doi.org/10.1016/S1048-9843(01)00064-9

Boldt, E. D. (1978). Structural tightness and cross-cultural research. Journal of Cross-Cultural Psychology, 9 , 151-165. http://dx.doi.org/10.1177/002202217892003

Bond, M. H., Leung, K., Au, A., Tong, K. K., \& Chemonges-Nielson, Z. (2004). Combining social axioms with values in predicting social behaviors. European Journal of Personality, 18, 177-191. http://dx.doi.org/10.1002/per.509

Burns, J. M. (1978). Leadership. New York: Harper \& Row Publishers.

Carpenter, S. (2000). Effects of cultural tightness and collectivism on self-concept and causal attributions. Cross-Cultural Research, 34, 38-56. http://dx.doi.org/10.1177/106939710003400103

Chemers, M. M. (1997). An integrative theory of leadership. London: Lawrence Erlbaum Associates.

Chen, X., \& Farh, J. (1999). The effectiveness of transformational leader behaviors in Chinese organizations: Evidence from Taiwan. Presentation at the National Meetings of the Academy of Management. Chicago, IL.

Conger, J. A. (1990). The dark side of leadership. Organizational Dynamics, 19(2), 44-55. http://dx.doi.org/10.1016/0090-2616(90)90070-6

Conger, J. A., \& Kanungo, R. (1987). Toward a behavioral theory of charismatic leadership in organizational settings. Academy of Management Review, 12, 637-647.

Conger, J. A., \& Kanungo, R. (1998). Charismatic leadership: The elusive factor in organizational effectiveness. San Francisco, CA: Jossey-Bass.

Dorfman, P. W. (2004). International and cross-cultural leadership research. In B. J. Punnett \& O. Shenkar (Eds.), Handbook for international management research (2nd ed., pp. 265-355). Ann Arbor, MI: University of Michigan.

Dorfman, P. W., \& House, R. J. (2004). Cultural influences on organizational leadership. In R. J. House, P. J. Hanges, M. Javidan, P. W. Dorfman \& V. Gupta (Eds.), Culture, leadership, and organizations: The GLOBE study of 62 societies (pp. 51-73). Thousand Oaks: Sage

Downton, J. V. (1973). Rebel leadership: Commitment and charisma in the revolutionary process. New York: Free Press.

Earley, P. C., \& Mosakowski, E. (2002). Linking culture and behavior in organizations: Suggestions for theory development and research meth-odology. In F. Dansereau \& F. J. Yammarino (Eds.), Research in multi-level: The many faces of multi-level issues (pp. 279-319). San Francisco: Elsevier Science. http://dx.doi.org/10.1016/S1475-9144(02)01038-X

French, J. R. P., \& Raven, B. (1959). The bases of social power. In D. Cartwright \& A. Zander (Eds.), Group dynamics (pp. 150-167). New York: Harper \& Row.

Gardner, J. W. (1989). On leadership. New York: Free Press.

Gelfand, \& Michele, J. et al. (2011). Difference between tight and loose cultures: A 33-nation study. Science, 332, 1100-1104. http://dx.doi.org/10.1126/science.1197754

Gelfand, M. J., Erez, M., \& Aycan, Z. (2007). Cross-cultural organizational behavior. Annual Review of Psychology, 58, 479-514. http://dx.doi.org/10.1146/annurev.psych.58.110405.085559

Gelfand, M. J., Nishii, L. H., \& Raver, J. L. (2006). On the nature and importance of cultural tightness-looseness. Journal of Applied Psychology, 91, 1225-1244. http://dx.doi.org/10.1037/0021-9010.91.6.1225

Graham, J. W. (1987). Transformational leadership: Fostering follower autonomy, not automatic followership. In 
J. G. Hunt (Ed.), Emerging leadership vistas. Boston: Lexington Books.

Hofstede, G. (1980). Culture's Consequences: International Differences in Work-Related Values. Beverly Hills, CA: Sage.

Hofstede, G. (1991). Cultures and organizations: The software of the mind. New York: McGraw-Hill.

Hofstede, G., \& Bond, M. H. (1988). The Confucian connection: from cultural roots to economic growth. Organizational Dynamics, 16(4), 5-21. http://dx.doi.org/10.1016/0090-2616(88)90009-5

House, R. J., \& Howell, J. M. (1992). Personality and charismatic leadership. The Leadership Quarterly, 3, 81-108. http://dx.doi.org/10.1016/1048-9843(92)90028-E

House, R. J., \& Shamir, B. (1993). Toward the integration of transformational, charismatic, and visionary theories. In M. M. Chemers \& R. Ayman (Eds.), Leadership theory and research: Perspectives and directions (pp. 81-108). San Diego: Academic Press.

House, R. J., Hanges, P. J., Ruiz-Quintanilla, S. A., Dorfman, P. W., Javidan, M., Dickson, M. W., Gupta, V. (1999). Cultural influences on leadership and organizations: project GLOBE. In W. H. Mobley, M. J. Gessner \& V. Arnold (Eds.), Advances in Global Leadership (pp. 171-233). Stamford, CN: JAI Press.

House, R. J., Wright, N. S., \& Aditya, R. N. (1997). Cross-cultural research on organizational leadership: A critical analysis and a proposed theory. In P. C. Earley \& M. Erez (Eds.), New perspectives in international industrial/organizational psychology (pp. 535-625). San Francisco: New Lexington Press.

Javidan, M., \& Carl, D. E. (2005). Leadership across cultures: A study of Canadian and Taiwanese Executives. Management International Review, 45(1), 23-44.

Javidan, M., House, R. J., \& Dorfman, P. W. (2004). A nontechnical summary of GLOBE findings. In R. J. House, P. J. Hanges, M. Javidan, P. W. Dorfman \& V. Gupta (Eds.), Culture, leadership, and organizations: The GLOBE Study of 62 societies (pp. 29-48). Thousand Oaks, CA: Sage.

Lunenburg, F. C. (2012). Power and Leadership: An Influence Process. International Journal of Management, Business, and Administration, 15(1), 1-9.

Markus, H. R., \& Kitayama, S. (1991). Culture and self: Implications for cognition, emotion, and motivation. Psychological Review, 98, 224-253. http://dx.doi.org/10.1037/0033-295X.98.2.224

Masi, R. J., \& Cooke, R. A., (2000). Effects of transformational leadership on subordinate motivation, empowering norms, and organizational productivity. International Journal of Organizational Analysis, 8(1), 16-47. http://dx.doi.org/10.1108/eb028909

Miller, J. G. (1994). Cultural diversity in the morality of caring: Individually oriented versus duty-based interpersonal moral codes. Cross Cultural Research, 28, 3-39. http://dx.doi.org/10.1177/106939719402800101

Miller, M. (2007). Transformational leadership and mutuality. Transformation, 24(4), 180-185.

Pelto, P. (1968). The difference between "tight" and "loose" societies. Transaction, 5, 37-40.

Peter, G., \& James, S. (2013). China: Transformational Leadership for Policy and Product Innovation. Advances in Management, 6(5), 3-10.

Schwartz, S. H. (1992). Universals in the content and structure of values: Theoretical advances and empirical tests in 20 countries. In M. Zanna (Ed.), Advances in Experimental Social Psychology (Vol. 2, pp. 1-66). New York: Academic Press.

Shamir, B. (1991). The charismatic relationship: Alternative explanations and predictions. Leadership Quarterly, 2, 81-104. http://dx.doi.org/10.1016/1048-9843(91)90024-V

Taras, V., Kirkman, B. L., \& Steel, P. (2010). Examining the impact of Culture's Consequences: A three-decade, multilevel, meta-analytic review of Hofstede's cultural value dimensions. Journal of Applied Psychology, 95, 405-439. http://dx.doi.org/10.1037/a0018938

Triandis, H. C. (1989). The self and social behavior in differing cultural contexts. Psychological Review, 96, 506-520. http://dx.doi.org/10.1037/0033-295X.96.3.506

Triandis, H. C. (1994). Culture and social behavior. New York: McGraw-Hill.

Triandis, H. C. (1995). Individualism and collectivism. Boulder, CO: Westview Press.

Trompenaars, A. (1993). Riding the waves of culture: Understanding cultural diversity in business. London, 
England: Economist Books.

Vandello, J. A., \& Cohen, D. (1999). Patterns of individualism and collectivism across the United States. Journal of Personality and Social Psychology, 77, 279-292. http://dx.doi.org/10.1037/0022-3514.77.2.279

Weber, M. (1947). The theory of social and economic organization. Glencoe, IL: The Free Press.

Yokochi, N. (1989). Leadership styles of Japanese business executives and managers: Transformational and transactional. Unpublished doctoral dissertation, United States International University, San Diego, CA.

Yukl, G. (1999). An evaluation of conceptual weaknesses in transformational and charismatic leadership theories. Leadership Quarterly, 10, 285-305. http://dx.doi.org/10.1016/S1048-9843(99)00013-2

Yukl, G. (2002). Leadership in organizations (5th ed.). Upper Saddle River, NJ: Prentice Hall.

\section{Copyrights}

Copyright for this article is retained by the author(s), with first publication rights granted to the journal.

This is an open-access article distributed under the terms and conditions of the Creative Commons Attribution license (http://creativecommons.org/licenses/by/3.0/). 